\title{
Hysteria, Madness and Disciplinary Power: The Next Room and Mrs. Packard
}

\author{
Sinan GÜL ${ }^{1}$
}

\begin{abstract}
Mrs. Packard (2008) by Emily Mann and The Next Room or The Vibrator Play (2009) by Sarah Ruhl explore and deplore the conventions of the $19^{\text {th }}$ century life-style while revealing the difficulties women experienced through the means of medical advances. Protesting the appropriation of scientific methods to oppress women's body and mind, both plays display examples of alternative methods to resist oppression despite being written in different tones, styles, and for different purposes. Using Foucault's formation of power and resistance theory to trace the theme of protest in both plays, this paper analyzes their relevance to contemporary audiences by emphasizing their break from the Enlightenment values and modern institutions.
\end{abstract}

\author{
Keywords \\ hysteria \\ madness \\ feminist history plays \\ Mrs. Packard
}

About Article

Received: 29.03.2021

Accepted: 08.06.2021

Doi:

10.20304/humanitas.905163

\section{Histeri, Delilik ve Disiplin Edici Güç: The Next Room ve Mrs. Packard}

$\ddot{O} z$

Emily Mann'in Mrs. Packard (2008) ve Sarah Ruhl'un The Next Room veya The Vibrator Play (2009) adlı oyunları, kadınların tıbbi gelişmeler dolayısıyla yaşadıkları sıkıntıları sergilerken, on dokuzuncu yüzyıl yaşam tarzının geleneklerini irdeleyip zorlukları sahneye aktarmaktadır. Farklı tonlarda, tarzlarda ve farklı amaçlarla yazılmış olmasına rağmen, her iki oyun da kadın bedenini ve zihnini baskı altında tutmak için bilimsel yöntemlerin kullanılmasını eleştirip, mevcut baskıya direnmek için alternatif yöntem örnekleri sergilemektedir. Her iki oyunda da protesto temasının izini sürmek için Foucault'un iktidar oluşumunu ve direniş teorisini kullanan bu makale, bu oyunlardaki Aydınlanma çağı değerlerinden ve modern kurumlardan kopuşlarını vurgulayarak çağdaș izleyicilerle kurulabilecek ilgi ve ilișkilerini analiz etmektedir.

\author{
Anahtar Sözcükler \\ histeri \\ delilik \\ feminist tarihsel oyunlar \\ Mrs. Packard
}

Makale Hakkında

Geliş Tarihi: 29.03.2021

Kabul Tarihi: 08.06.2021

Doi:

10.20304/humanitas.905163

\footnotetext{
1 Asst. Prof. Dr., National Defense University, Foreign Languages Department, Ankara/Turkey,
} sgul@kho.edu.tr, ORCID: 0000-0002-4529-6699 


\section{Introduction}

Explaining feminist history plays, Katherine E. Kelly points out that "A history play does not replicate the work of history writing, which records events to answer "truthfully" the basic questions of who, what, where, and when in relation to those events" (Kelly, 2010, p. 660). Thus, while scrutinizing a historical event, a feminist history play seeks answers about how the gender and identity roles have been constructed in a society. Furthermore, a feminist history play "invites the audience to know again - to undo and redo - the past in the present performance and in the absence of scientific truth claims made by official history" (Kelly, 2010, p. 660). In accordance with Kelly's definition, Mrs. Packard (2007) and In the Next Room (2009) challenge the understanding imposed by official history and highlight personal sufferings of women to undo and redo the past in the present performance.

Mrs. Packard and In the Next Room are examples of feminist history plays, which "provoke[d] a rethinking of historical periodization, categories of social analysis, and theories of social change" (Kelly, 2010, p. 646). Both Mann and Ruhl focus on female characters that are under attack through patriarchal values because determinant sexual division of authority and sexual order exclude and, to a certain extent, forbid those characters' involvement within sexual and social recreation. Kelly explains how the late nineteenth and early twentieth centuries became an appealing inspiration center for feminist history plays as they were both "a period of possibilities - sometimes short-lived or even false, but clearly imagined and inspiring-for many groups of women" (Kelly, 2010, p. 653). In addition, it was a time of awakening for many women like Mrs. Packard who did not consent to the dogmas of time and resisted them in favor of a change and reformation. Women strived to liberate their bodies and regain their identities independent of their husbands or fathers during late nineteenth century and early twentieth century. Both Ruhl and Mann's rearrangement of historical chronology offers different methods of resistance, such as sexual discovery, writing and solidarity among women, to memorialize the difficulties women had to suffer because of medical advances used as an excuse for limiting the social and cultural borders of women's body and mind.

As an explanation to the evolution of mental treatment, from which particularly women suffered heavily, from medieval times to modern times, Foucault scrutinizes the hegemonic position of psychology used for suppressing certain groups in a perpetual state of domination under the disguise of treatment and healing. This kind of suppression is manifest in Sarah Ruhl's dark comedy The Next Room or the Vibrator Play in which she employs a double strategy to unfold the elements of coercion and compulsion in social interactions while 
Gül, S. (2021). Hysteria, madness and disciplinary power: The next room and Mrs. Packard. Humanitas, 9(18), 130-150.

showing how relations of power constantly permeate medical treatments as well as domestic affairs when it comes to curing sexual deviance. In accord with Ruhl's concern about relations of force but different in tone and style, Emily Mann illustrates how power, through medical institutions, is exercised wrongfully in Mrs. Packard, whose protagonist, Elizabeth Parsons Ware Packard, is confined to an insane asylum by her husband reverend Theophilus (Theo) Packard after 22 years of their union. Despite being written in different tones, styles, and for different purposes, both plays surface a network of oppression aiming to cripple female mind and body through imposed consents of female characters. What appeals to contemporary audiences in these texts, I assume, is the power dynamics which has changed its façade, but remains in a similar form for many layers of the society.

The radiance of Foucault's definition of power comes from its diabolical formation which keeps resistance always in company: "Where there is power, there is resistance, and yet, or rather consequently, this resistance is never in a position of exteriority in relation to power" (Foucault, 1990, p. 95). This appealing force of resistance makes both Mann and Ruhl's texts powerful because they show a minor but strong vein of resistance in local patterns of power that endows men with dominion over women. The rationality of power, as an extension of The Enlightenment, is characterized by the installation of mental illness as an excuse to hinder women's independence and self-realization. Medical boundaries on defining women's problems have been used to ignore, hide, and maintain the unfair treatment despite its illogical and unethical methods. Mann explores the concept of madness in her play whereas Ruhl unfolds how hysteria has been exclusively reserved as an umbrella term to cover and dismiss identity problems. Madness was opposed to reason, however, unreason (deraison) became a device to interpret our culture's flaws and deficiencies.

Mann and Ruhl both explore and condemn the conventions of the nineteenth century life-style that Foucault reviews in different parts of his The History of Sexuality and The Madness and Civilization. Foucault states that madness has evolved in time to become a weapon in the hands of rulers to shut away dissident ideas as well as mentally ill. Thus, ruling classes adapted madness as a concept to justify confinement for other deviants. Clinic and medicine become a kind of deus ex machina for women whose feeble nature needs to be cured. Clearly, Mrs. Packard is a victim of such repression and her joining a Methodist church became the main ground for her incarceration after Theo's declaration of her insanity, rather than a public hearing at that time. Her story becomes an alternative for history which celebrates the nineteenth century as the pinnacle of Western achievement and the expansion 
Gül, S. (2021). Hysteria, madness and disciplinary power: The next room and Mrs. Packard. Humanitas, 9(18), 130-150.

of American mind as well as culture. Mann forges a link to the national past, which was characterized by silence and absence for women. Thus, Mrs. Packard exposes gaps in official history: Her commemoration becomes a tribute to her deeds and memory which shows that "In a general way, then, madness is not linked to the world and its subterranean forms, but rather to man, to his weaknesses, dreams, and illusions" (Foucault, 1990, p. 26).

On the other side, Ruhl's uses of parody and irony also signal her characters' resistance to the determining forces of power. Mann criticizes the harsh conditions of medical institutions while Ruhl satires a gentler way of punishment on sexual deviants by focusing on a single key theme within the classical conception of madness: hysteria, which is one of four themes that Foucault relates with the classical definition of madness together with melancholia, mania and hypochondria (Foucault, 1990, p. 28). Ruhl's text unfolds through a vigorous blend of comedy and concealed coercion, resulting in an idiosyncratic combination of laughter, shock, and bewilderment that has a discomforting effect on audiences. Two protagonists of the play, Mrs. Daldry and Mrs. Givings, elude power through their search for orgasm and their solidarity challenges patriarchal conceptions of traditionally male-focused historiography found expression in the books Ruhl read prior to writing her play. Their physical search for a release displays an escape from the boundaries of the society over their bodies. The performative-quality of writing history reveals "a gigantic moral imprisonment," (Foucault, 1990, p. 551) as Foucault defines it, while showing how performative expectations of society still determine the norms over individuals. In other words, these protagonists do not have the control over their bodies as others particularly men dictate how to feel or what to do with their physiological processes.

\section{Mrs. Packard}

Mann talks about the torturing of prisoners in Abu Ghraib, Iraq, when she is asked how this play, which takes place mostly in the asylum in Illinois between 1861 and 1864, speaks to the present. She criticizes religious fanaticism and absolute power, which corrupts those who hold authority in their hands. (Langworthy, 2014) Similarly, theatre critic Peter Marks compares Mrs. Packard to Arthur Miller's The Crucible (1953) and argues how both plays are "about the martyrdom of those who dare to tell the truth when powerful, hidebound institutions demand they tow the line." Moreover, Mann defines her plays to be "about giving voice to the voiceless," and she adds that "Elizabeth's voice was not only almost silenced in her own day, but like many women, her story has nearly disappeared from history" (Langworthy, 2014). She cites Emily Dickinson's poem in her dedication to the play: "Tis the 
Gül, S. (2021). Hysteria, madness and disciplinary power: The next room and Mrs. Packard. Humanitas, 9(18), 130-150.

majority/In this, as all, prevails./ Assent, and you are sane;/ 'Demur,--you're straightaway dangerous,/ And handled with a chain." (Mann, 2013, p. v) Majority is an important concept for Mann because she uses this biographical story as a springboard for delineating modalities of power. Any sensible person of the $21^{\text {st }}$ century would abhor what Mrs. Packard's went through, but Mann displays the social network of production (the doctor-patient, husbandwife relationship), which creates persecuted individuals because of their beliefs, ideas, identities, or tendencies, still exists anytime and anywhere. There are no Mrs. Packards in contemporary times, but there are variations of her in subdued forms that Mann puts under spotlight throughout her story.

In the beginning of Mrs. Packard, Dr. Andrew McFarland talks to Theo and his wife, and he promises special privileges while Elizabeth is in the institution. This conversation indicates that McFarland is aware of the situation and despite Elizabeth's sane condition, her husband's testimony is more powerful, as the law indicates, than the reality. Elizabeth is aware of her husband's flaws and this is one of the reasons that she cannot accept the superiority of his ideas or personality. Her husband Theo had a vision after his brother died in his arms and after that he quit drinking and entered seminary. This situation demonstrates how Theo's devotion is because of practical reasons rather than a free-willed choice in his relation with God and his congregation as a minister. In other words, Theo is not a devout Christian, but his position as a clergy member has salvaged him from his atrocious life-style so his intentions and motives as a preacher are questionable. However, as other members are also aware of his personal fallacies, they all counsel Elizabeth to ignore and respect her husband the way he is. Most of the unfair treatment that Elizabeth experiences stems from the law passed in 1851 in the state of Illinois, which allowed that "married women ..., who, in the judgment of the medical superintendent are evidently insane or distracted, may be entered or detained in the hospital on the request of the husband of the woman ... without the evidence of insanity required in other cases" (Rendell). Disciplinary power strives to make Elizabeth more obedient through confinement legalized by laws and institutions. Similar to what Foucault described through Bentham's design for an ideal prison, the Panopticon, Mann shows a power mechanism that transforms the body through observation and analysis.

As a response to all efforts of subjugation, writing becomes a special method of therapy as well as a means of mental resistance for Elizabeth who has been targeted through isolation. McFarland also encourages her to express her feelings and use writing as a means of relief as long as it is not subversive. Mann demonstrates how personal writing is another way 
Gül, S. (2021). Hysteria, madness and disciplinary power: The next room and Mrs. Packard. Humanitas, 9(18), 130-150.

to record history in the play because this play is a testimony to Elizabeth's writings as her notes and letters constitute the backbone of Mann's dramatic structure. While Elizabeth writes her memoirs on stage, she actually writes the core of the play and this creates a feeling of a play within a play. This self-cognitive move creates a lineage of writing among women particularly between Mrs. Packard and Mann. At the same time, it recognizes the creative abilities of female writers as well as establishing solidarity because Packard's story was not well known until the production of Mann's play. Nevertheless, Mann pays tribute to Mrs. Packard's struggles and substantiates her memoirs by converting them into a different format.

Mrs. Packard could be considered as a literary recorder of her time because the method of spreading ideas through writing is a strong element of Mrs. Packard. Elizabeth Packard wrote two books to describe her suffering during her confinement. Although there were many autobiographical elements in them, the first one, Modern Persecution or Married Woman's Liabilities as Demonstrated by the Action of the Illinois Legislature (1874) keeps an account of Mrs. Packard's difficulties after being kidnapped from her own home by the authorities. The second book is called The Prisoners' Hidden Life, Insane Asylums Unveiled (1868) and gives a detailed description of the brutal treatment Elizabeth and other patients experienced. Thus, recording becomes Elizabeth's way of resistance against everyone who wants to silence her. Mann exemplifies a way of refusing institutional oppression gracefully by linking Elizabeth's habit of writing to resistance against the clinical techniques of the asylum which seize her individuality. Her situation is reminiscent of Foucault's definition of disciplinary power's permeability in his History of Sexuality: "Power is everywhere: not that it engulfs everything, but that it comes from everywhere" (Foucault, 1991, p. 77). Mann illustrates through Elizabeth's story that resistance is as prevalent as the power despite the surveillance and subsequent objectification of the body. Mann displays the liberating impact of writing on Elizabeth. The writing becomes a venue for Elizabeth to show her determination and belief in how individuals can maintain their dignity under bodily pressure since she had to wear a straightjacket. However, writing enables Elizabeth to protect her sanity and at the same time makes it possible for other generations to learn about her story. Ironically, Elizabeth's liberation from the asylum also depends on a piece of writing, an affidavit that she needs to sign, so that she will "honor and obey [her] husband in all things - that [she] will be his unconditional help-mate and support in his church, in his home, and in his bed" (Mann, 2013, p. 39). 
Gül, S. (2021). Hysteria, madness and disciplinary power: The next room and Mrs. Packard. Humanitas, 9(18), 130-150.

In addition to being a written record of social oppression over women, Elizabeth's story is a testimony to the brutal treatment that the patients encounter daily in the asylum. They are subjected to abusive treatment although some of the patients have no indication of any mental disorder just like Elizabeth. Hospital becomes an institution designed for disciplinary de-individuation of patients. She is placed in with other rational women whose stories are, to a certain extent, similar. Elizabeth explains why she is in the asylum: "Doctor ... my husband is jealous. His congregation is dwindling. I $-\mathrm{I}$ encouraged ... healthy discussion! ... The Christ I worship and love would not have an innocent baby damned at birth, Theophilus! It is woman who will crush the serpent's head!" (Mann, 2013, p. 12). Her refusal of the Calvinist values about the original sin float to the surface and she cannot hide her anger. The asylum superintendent, McFarland, treats Elizabeth well and shows fondness for her. He pushes Elizabeth to admit that her actions have been irrational and to apologize to her husband. This is his condition to release her. However, Elizabeth is too proud to accept such a deal and she underestimates McFarland's part in hospital's oppressive system since he is a "kind" man. Naively, she asks his help for her release with all other sane patients. When she calls the asylum a prison, McFarland bursts out: "Prison? This is not a prison, Mrs. Packard! The women who are patients here must be kept here for their own health and protection and for the protection of their children" (Mann, 2013, p. 53). McFarland reverses the family appeal Elizabeth uses to convince him. Family, which this institution supposedly protects, is an excuse that the oppressor and the oppressed use. This confrontation brings Elizabeth's happy days to an end, and she is sent to the eighth ward where she is deprived of all her privileges. McFarland's personal merits fail to cloak his and medical world's flaws when his authority is challenged and this enables Elizabeth to understand that it's the system which she should fight rather than take refuge under the wings of certain individuals.

In the second act, Elizabeth tries to restore and clean the eighth ward with the help of a kind, but ineffectual attendant. When McFarland finds out that Elizabeth has been keeping record of her experiences despite his warnings, she is forced to wear a straitjacket in solitary confinement. However, Elizabeth finally gets a second chance to go to court when visiting asylum overseers talk to her. Once a jury realizes her sanity, she is released, but her husband locks her up in their home and keeps abusing her.

At the end, it is clear that Mann scrutinizes Elizabeth's strong will against total submission through her character. This revolt against institutional oppression shows that her refusal to recant her liberal views of religion is not a whimsical stubbornness or personal 
Gül, S. (2021). Hysteria, madness and disciplinary power: The next room and Mrs. Packard. Humanitas, 9(18), 130-150.

vendetta between her husband and Elizabeth. Her struggle, after a while, becomes a bigger issue and transforms into a national debate between her and society thanks to her publications and dignity. Sandra F. VanBurkleo points out the significance of Elizabeth and her writing:

Few historians of American reformism doubt Packard's achievements: her books were widely read and her legislative campaigns uncommonly effective. Before her death in July 1897, and notwithstanding more than a few heartbreaks ... many states gradually adopted the reforms that Packard proposed. Moreover, McFarland had met his match: in the end, he lost not only his post but also his ability to persuade professional colleagues that "moral insanity" was a meaningful, ethical diagnosis (VanBurkleo, 2011, p. 19).

Elizabeth realizes that this is not about her husband or the doctor as she recognizes the traces and patterns of the same work everywhere. What she rejects is the life imposed on her, and she is willing to fight to get what she really deserves and desires.

On a different level and through historical examples, in Madness and Civilization, which takes a central place in the historiography of institutional oppression over individuals, Foucault analyzes social and individual mechanisms behind the Western penal systems through empirical evidences, and points out that unreasoning has been used to condemn "sexual offenders, those guilty of religious profanation, and free-thinkers (les libertins)" (Gutting, 2005, p. 55) as well as the mad. He emphasizes that the internment did not have any medical purposes, but it was rather to isolate 'the mad' from social environments with which they differed. This isolation in Mrs. Packard's case has replenished her rebellious side and led her to a personal salvation. A revolutionary way opens up several paths for Elizabeth, and the reversal of such a journey is almost impossible despite the hardships. Elizabeth risks her wellbeing by opposing her doctor's opinions and his treatment of other patients. Eventually, her unbending character causes her to end up in a worse surrounding with more mentally unstable patients. Although Elizabeth remains married after the long confinement and retrials, she and her husband are estranged for the rest of their lives. She becomes an activist who lobbies for the rights of women, and plays an important role in changing the commitment laws in four different states. Mental illness was considered a sign of witchcraft or demonic possession for a long while and the mentally ill were confined in prisons, monasteries, or homes. In time, vigilantes like Mrs. Packard improved the appalling conditions for the mentally ill after witnessing the outrageous situations in prisons. Jacksonville Insane Asylum opened in 1851 after such efforts to create a better place to treat the patients. 
Gül, S. (2021). Hysteria, madness and disciplinary power: The next room and Mrs. Packard. Humanitas, 9(18), 130-150.

Foucault's emphasis on correctional administrative internment tells how it restricts the liberating and humane characteristics of the individuals through a strict regime of moral management. Foucault explains the genealogy of the abnormal and the asylum to show how "the Enlightenment incriminates modern urban luxury and idle affluence; the nineteenth century denounces proletarian degeneracy and idle poverty" (Gordon, 2013, p. 97). People who are confined for society's welfare appear as residues of evolution. Socially superior classes, as Foucault points out, use madness to maintain their privileges. In this case, Theo and Dr. McFarland are protectors of status quo. In addition to madness, family becomes another blackmailing point as the nineteenth century value system honors the family over the individual. In a way, a woman's existence is dependent on her family and by separating Mrs. Packard from her children; she is figuratively detached from her reasons for living. When she realizes that family is a significant part of women's contract with society, she expresses her bitter feelings:

I could never, ever regret having my six children, don't misunderstand me, but ... the price to pay is quite high, don't you think? I now better understand those women who choose not to marry. I could never understand them before! Or women who want to vote? I'm thinking very hard about them at the moment ... (Mann, 2013, p. 26)

The hard choice between her family and independence restricts Elizabeth's power over her decisions and actions. Used against her, Elizabeth's children become a symbol of her husband's power over her. Her kids are taken from her for the same reasons that her sanity is desired to be taken away by her husband. She is indirectly reminded that everything she has can be taken through legal and illegal methods. The reason that she fights as an activist when she is out of the prison comes from the fact that she has realized how desperate women are compared to men under the provisions of this system.

Unlike Mann's other plays, this is not a documentary, but despite its creative structure and composite characters, Mann adheres well to historical facts. For example, the court recordings and testimonies show how unbelievable and torturous Elizabeth's confinement has been because the accusations against her are illogical and subjective. Mann creates an imagery of the majority that oppress an individual. Mann distinguishes Mrs. Packard from her documentary plays and defines it as liberating:

It took a combination of all the skills used in writing a documentary-research, editingbecause in fact this is inspired by a true story. But it gave me complete freedom to know what the bones of the story were and then fill in from there and create characters and make scenes and tell a story from my imagination. That's been the great fun of it. If I needed a scene, I 
Gül, S. (2021). Hysteria, madness and disciplinary power: The next room and Mrs. Packard. Humanitas, 9(18), 130-150.

could write it. I didn't somehow have to construct it out of spoken word or found text (Reported in Langworthy, 2014).

Free from the boundaries of following a verbatim of historical events, Mann clearly establishes an oppressive system which justifies Elizabeth's detainment in order to manipulate her thoughts and her future as her ideas are threatening to current norms of the society. As Mrs. Chapman in the play points out: "They call it "subduing the patient"” (Mann, 2013, p. 35). The potential danger manifested through her objection of Calvinist teachings harms the image of obedient subject and, therefore, she needs to be reformed. However, at the end, what goes through a reformation is the oppressive system, not her.

\section{In The Next Room or The Vibrator Play: Hysteria In Action}

Ruhl's In the Next Room or the Vibrator Play unfolds the issues of marriage, breastfeeding, the invention of the vibrator, and hysteria through the relationship between a doctor and his patients as well as a husband and a wife. Historical facts in Ruhl's text become a springboard to start a conversation on the problems of intimacy, marriage, and sex. Ruhl started to write the play after reading a book; Rachel P. Maines' The Technology of Orgasm (1999), which accounts the history of a new electrical device used to cure women diagnosed with hysteria (Farmer, 2015, p. 360). Next Room is clearly a product of an extensive study, and Ruhl warns her readers about the authenticity of the events in the play: "Things that seem impossibly strange in the following play are all true - such as the Chattanooga vibrator-and the vagaries of wet nursing. Things that seem commonplace are all my own invention" (Ruhl, 2010, p. 6). Next Room, as Ruhl claims, is loyal to historical characters and events, combining several different topics under one dramatic structure. There is also a personal aspect of the play: Ruhl wrote while nursing her own newborn baby.

The play takes place in a prosperous spa town outside New York City circa 1880s around the dawn of the age of electricity. Critical of alienation among people, the play takes place under the heavy mannerism of the Victorian age embraced by the approaching era of electricity, technology, and sexuality. Diagnosis and treatment of hysteria, like madness, was subjective and unscientific as illustrated in Mrs. Packard. No longer used to describe patients' symptoms, hysteria was a commonly used phenomenon to send women to an asylum or to undergo surgical hysterectomy. In other words, everything that bothered people about these women was often a result of hysteria. This might sound funny or preposterous to contemporary audiences, but the American Psychiatric Association kept using the term until the early 1950s (Gilman, 1980, p. 37). Although its meaning has evolved into different 
Gül, S. (2021). Hysteria, madness and disciplinary power: The next room and Mrs. Packard. Humanitas, 9(18), 130-150.

implications, it has not been easy for women to remove the labels of crazy and hysterical. At the end of the $19^{\text {th }}$ century, great advances were made in the diagnosis and treatment of hysteria "by the recognition of its psychogenic nature and by the use of hypnotism to influence the hysteric patient" (Thornton, 1976, p.43). Sigmund Freud, who was a pioneer with other scientists such as Joseph Breuer, J.M. Charcot, and Pierre Janet, concluded that "hysterical symptoms were symbolic representations of a repressed unconscious event, accompanied by strong emotions that could not be adequately expressed or discharged at the time" (Thornton, 1976, p. 47). Before Freud's studies, "it was believed that hysteria was the consequence of the lack of conception and motherhood" (Gordon, 2013, p. 28). Freud advanced his studies and focused on psychology and the unknown of the human mind. His conversationalist approach rather than an imposing method changed the treatment for mental illnesses.

While explaining how stereotypes and idealized figures manipulate women's decisions in the advertising industry, Mady Schutzman gives a brief but insightful account of hysteria in The Real Thing: Performance, Hysteria, and Advertising:

Hysteria was in large part a silent scream of distress. The late nineteenth century was a time of radical change: industrial capitalism was expanding at a rapid pace, men were losing a sense of mastery in the workplace due to mechanization, women were entering the public sphere, a middle-class women's movement was flourishing, medical science was typologizing madness, and the advent of the ad agency standardized representations of gender. ... Hysterical symptoms were endless; they invented themselves as rapidly as the social body invented ways to displace societal power conflicts onto the female body as if they belonged to her. Hysteria in women was, and still is, a reflection of the male hysteria of dominant culture (Schutzman, 1999, p. 2).

While criticizing the lack of romantic advances in a relationship, Ruhl addresses the concept of hysteria created by the dominant male culture. Her character Mr. Daldry exemplifies the personal and social expectation from medical science for men to cure their partners when he drops his wife at the doctor's office. For him, his wife is ill and needs to be treated. He does not show any affection for his wife and he seeks love from other women like Mrs. Givings.

An admirer of technological advances, Dr. Givings is equal to a modern day psychologist who suggests pharmaceutic or therapeutic solutions to patients with psychological problems. Psychology, as a separate branch of treatment, was not known in the nineteenth century, although there were scientific steps that would eventually assist Freud and his colleagues to interpret mental difficulties their patients experienced. Herb specialists, 
Gül, S. (2021). Hysteria, madness and disciplinary power: The next room and Mrs. Packard. Humanitas, 9(18), 130-150.

medicine makers, medical and religious scholars, have used hysteria for centuries to produce what Foucault defines as docile bodies, bodies that not only do what we want but do it precisely in the way that we want (Foucault, 1995, p. 138). Pieter van Foreest suggested a peculiar method as a cure for hysteria in a medical compendium published in 1653:

When these symptoms indicate, we think it necessary to ask a midwife to assist, so that she can massage the genitalia with one finger inside, using oil of lilies, musk root, crocus, or [something] similar. And in this way the afflicted woman can be aroused to the paroxysm. This kind of stimulation with the finger is recommended by Galen and Avicenna, most especially for widows, those who live chaste lives, and female religious, as Gradus [Ferrari da Gradi] proposes; it is less often recommended for very young women, public women, or married women, for whom it is a better remedy to engage in intercourse with their spouses (Maines, 1999, p. 1).

Historically, as Next Room and Mrs. Packard exemplify, women's problems were considered to be either in their head or in womb of which men claimed authority throughout time. Although women have obtained some independence from a patriarchal dominance over their bodies particularly in the last 100 years, laws still restrict women about the issues of abortion or mental counseling in different parts of the world. Dr. Givings' paraxial sessions are a classic example to hierarchical observation through which he can have a vantage point to look over his subjects. His table is not a Panopticon to control prisoners, but it is still an object of authority that normalizes judgment over his patients' docile bodies.

While the play conceptualizes such debates about authority over docile bodies, its reliance on daily events to advance the plot reminds the audience its realistic aspects of domestic life. For example, the Givings are looking for a wet nurse to feed their baby because Mrs. Givings' milk is not adequate to breastfeed their baby Letitia. Dr. Givings' patient Mrs. Daldry, whose hysterical attacks have been cured by the vibrator, has a housekeeper who has recently lost her baby. The first scene ends as Mr. and Mrs. Daldry leave to come back the next day with their housekeeper Elizabeth. Mrs. Daldry exemplifies a silenced and oppressed woman in her marriage. The way she is defined, "fragile and ethereal," leaning "heavily on her husband's arm, and "her face is covered by a veil attached to a hat" (Mann, 2013, p. 10), points to unfair power relationship in her marriage. The vibrator, a phallic symbol, substitutes sexual passion, but its existence takes the control from men and gives a feeling of relief to women. Although the vibrator reinvigorates the patients' sexual life, it also enables them realize what is missing in their lives in general. In the second scene, Elizabeth, whom Dr. Givings examines for diseases, starts breastfeeding Letitia. The first act ends with the 
Gül, S. (2021). Hysteria, madness and disciplinary power: The next room and Mrs. Packard. Humanitas, 9(18), 130-150.

solidarity of Mrs. Givings and Mrs. Daldry, who shows the doctor's wife how to use the vibrator because Mr. Givings does not allow his wife to use the vibrator.

In the second act, the focus of the play shifts to Mrs. Daldry, who cannot have orgasm the following day, despite the same application of the machine. Although it usually takes three minutes for a patient to reach a paroxysm, this unsuccessful session reveals her actual sexual tendencies and oppressed desires. When Dr. Givings' female assistant Annie starts a manual treatment, Mrs. Daldry reaches her sexual climax immediately. Mrs. Daldry's obvious attraction to Annie is a sign of her repressed (lesbian or bisexual) identity that prevents her from enjoying her marriage with her husband.

Although Ruhl provides a close look into the masculine world of the nineteenth century under a patriarchal system, she also portrays male characters that experience hardship because of what is expected from them. For example, Leo is an artist who has been diagnosed with hysteria and he has homosexual tendencies. Ruhl's characters are vivid examples of what Foucault describes as outcasts throughout his criticism of the Enlightenment. True to the spirit of the times, it would also be unacceptable to publicly announce their tendencies in such a community which defines same-sex sexual activity to be "driven by the innate corruption of fallen humanity" (Godbeer, 2002, p. 64). What drives Ruhl to include medical treatment in a play can be the stratification system that follows medical science in constructing cultural norms of appropriate sexual codes and identity. Ruhl targets medical science and medical societies and shows that oppression cannot be legitimate just because of its so-called association with scientific terms.

Despite the Enlightenment's reformative impact on Europe, the periods of both plays are highly influenced by the conservative Victorian age, which sees homosexuality as a crime that must be treated quickly or punished publically. Despite the idealization of same-sex friendship without any overt sexual attachments, Victorian morality shaped the midnineteenth century United States. There were gay bars in some urban areas around New York, but the rate of prosecutions for same-sex sodomy increased (Pickett, 2009, p. 188). The late (change) 19th and early (change) $20^{\text {th }}$ centuries saw the replacement of medical discourse instead of theological interpretations. As an extension of this switch, schools and hospitals were designed to cure homosexuality which became an issue for the sciences (Pickett, 2009, p. 191). In a way, Ruth responds to attempts of infamous medical treatments of homosexuality through Mrs. Daldry's attraction to her own sex. The machine is more 
Gül, S. (2021). Hysteria, madness and disciplinary power: The next room and Mrs. Packard. Humanitas, 9(18), 130-150.

effective over her body whenever a woman applies it to Mrs. Daldry's body and it gives away her subdued feelings and instinctive drives.

Ruhl's approach gradually turns Next Room into a criticism of modern inventions starting from Thomas Edison's electricity and light when Leo, one of Dr. Givings' patients, indicates their soulless form: "When Edison's light came out, they were all saying, my God! light like the sunset of an Italian autumn . . . no smoke, no odor, a light without flame, without danger! But to me, Mrs. Givings, a light without flame isn't divine - a light without flame..." (Ruhl, 2010, p. 77). Leo, who is an embodiment of artistic and homosexual sensitivities about art and love, provides a clear example of a character that has peculiar problems compared to the rest of society. His obsession with the Italian art and his fondness for Italy serves as a model for the European character who trusts feelings more than reason. Dr. Givings is the opposite character who believes in science and thinks that his machine can solve people's problems. However, as his wife's unhappiness testifies, technology can be relieving as long as humans are involved in it. Otherwise, it will just be "soulless technology" (Ruhl, 2010, p. 78), as Leo states.

Dr. Givings' reaction when he catches his wife's hand on Leo's cheek upsets his wife more because he acts extremely logical about it whereas Mrs. Givings would rather have him throw tantrums about it. When she asks why he is not pale with rage, Dr. Givings talks as an anger management instructor:

Pale with rage, exactly, in a sentimental novel. My point is: this is not the end of the book. You made a mistake, that is all. The treatment I gave you made you excitable. It is my fault. A hand on the cheek, these are muscles, skin, facts. It needn't mean that one is preferred absolutely, or that one isn't loved. So why then jealousy? My darling, I don't mind (Ruhl, 2010, p. 103).

Mrs. Givings confirms his apathy in the face of unexpected events or perplexities when Dr. Givings discovers Leo painting Elizabeth nursing their baby in their living room without his knowledge. When Dr. Givings pretends that nothing serious has happened, Mrs. Givings complains that he has no reactions or feelings: "As you see, he is a man of science. Nothing upsets or shocks him" (Ruhl, 2010, p. 109). Leo, on the other hand, compliments Dr. Givings for being rational: "What a capital husband you have. Completely beyond the dictates of modern society. I love your husband" (Ruhl, 2010, p. 109).

Ruhl establishes an indirect criticism of rationalism through Dr. Givings' character. For example, for Dr. Givings, to produce a paroxysm "was much like a child's game—-trying 
to pat the head and rub the stomach at the same time," and the invention of the vibrator has made things easier when he says that "thanks to this new electrical instrument we shall be done in a matter of minutes" (Ruhl, 2010, p. 16). He is the embodiment of practicality, briefness, and logical methodology. He is trained to understand other people's problems, but he cannot see the problems his wife suffers from because his scientific attitude prevents him from being sincere and close with her. As John Lahr points out, "There is no place for Catherine in the house, or in her husband's imagination. He literally and figuratively can't take her in." Even in the final scene where he gets together with his wife, he considers it as an experiment in which he is concerned about the outcomes. However, this sounds pragmatic and clearly against rationalist philosophy, so in a way rationalism is tailored to fit his agenda. Ruhl quietly questions this understanding of science through the laughter over entertaining images of vibrators, breastfeeding, and stereotypical characters. She indirectly asks if this was what rationalist policies have structured in our society in the past, how we can trust the present's rationalist society. The past becomes a model that projects light on society through its repetitive patterns despite being different in various political and cultural climates.

Sexuality as well as our past is an integral part of our identity as a reflection of selves or subjects and it serves a center of individual consciousness that doctors replace with an appropriated form. Doctors in both plays demand their patients to subject to a strict code of sexual ethics within the Western hermeneutics of the self that is replete with Christian morals and ethics. They both seem to be obedient followers of science, which has blinded them to the extent of hurting people around them. Ruhl's and Mann's account of the nineteenth century medical science is a contrast to most of the progress that took place during that era (Worboys, 2011, p. 112). Despite being knowledgeable, Dr. Givings and Dr. McFarland ignore their patients' privacy and identity. Science becomes a means of oppression that dictates consent of unwanted interceptions on the patients' bodies and spirit. Doctors in both cases become an omnipotent preacher of correction.

A man of science and enlightenment, Dr. Givings, ignores humane desires particularly his wife's, although he is knowledgeable about human anatomy. He is a male physician with uninformed prejudices on the subject of women's sexuality despite the optimist finale where he reconciles with his wife. Although Ruhl shows the medical incapability of the nineteenth century through Dr. Givings' character, she also cuts "across the grain of traditional history, which, by default, assumes the experiences of men to be normative" (Kelly, 2010, p. 660). 
Gül, S. (2021). Hysteria, madness and disciplinary power: The next room and Mrs. Packard. Humanitas, 9(18), 130-150.

Despite all problems, Dr. Givings proves that he can effectively express his sincerity through his science logic if he tries:

Dr. Givings: (kissing tenderly each place as he names it—they are all on the face)

I bless thee: temoporamandibular joint

I bless thee: buccal artery and nerve

I bless thee: depressor anguli oris

I bless thee: zygomatic arch

I bless thee: temporalis fascia

I bless thee, Catherine.

Mrs. Givings cries, it is so intimate (Ruhl, 2010, p. 84).

This scene, which reveals personal and scientific complications in Dr. Givings' character, brings the couple together and their domestic setting suddenly disappears. They find themselves in a sweet small winter garden where they end up making love. Is it their domestic surrounding and its burdens that created obstacles between the husband and the wife or is the medical progress that Doctor has complete confidence? Although this situation can be interpreted in different meanings, Mrs. Givings reaches orgasm on her husband at the finale and their sexual life and marriage are restored through this surrealist transcendence. Katherine E. Kelly finds a biblical commentary at the end:

Throughout the play, the milk-poor Mrs. Givings is linked with gardens and fertility, and at the play's close, she breaks out of the two-room set, leading her husband to the Edenic garden where they undress each other, lie down, and make angels in the snow. Thus Ruhl recasts the middle-class white woman as a sexualized being unintimidated by technology and undeterred by scientific objectivity (Kelly, 2010, p. 659).

Although Kelly's analysis offers an insightful reading, such a comparison reduces the significance of female awakening and resistance to oppression within the play. Mrs. Givings' orgasm is a victory of sensitive human nature against the cold medical procedure. More than a biblical reference, the final scene increases the romantic element that has been attributed to female sensitivity. Satirically, Ruhl questions this stereotypical attribution through an ironical portrayal of the Givings' comical situation.

Ruhl has used technology as a means of criticizing its present functions as her play hints at alienation between couples. Michial Farmer also describes Ruhl as a writer who "presents modern electric technology as a force destructive of nature and humanity but resists the temptation to posit any simple dismissal of the modern world as the key to human 
Gül, S. (2021). Hysteria, madness and disciplinary power: The next room and Mrs. Packard. Humanitas, 9(18), 130-150.

survival," and he adds that "instead she presents art as a countervailing force to modern technology, a tool to orient humans toward a proper perspective on Being itself" (Farmer, 2015, p. 353). The automation of close relations, particularly sexual encounters, has eliminated the charm of sincerity. Although contemporary society is far more advanced than the one Ruhl portrays, technology and modernity have caused more problems that could not be solved through any means they have created.

Rather than a rebellious way to change things completely, Mrs. Givings finds little holes to fill in her life to make it more durable. For example, she likes walking and taking naps, which is also a defiance of her husband's wishes. She loves going out and getting wet under the rain, which implies her seeking for a more passionate and maybe a stereotypical story in her life. At the end, Leo calls her "a fallen angel," when he finds her making snow angels and she responds to that compliment by saying that "Did I? Oh! I am cold, but the cold feels marvelous, I feel awake, my skin is tingling” (Ruhl, 2010, p. 61). Her feelings outside the conventions of her domestic setting release her and "awakens" her. She, like Mrs. Daldry, might be called hysteric or feeble, but once both of them are out of the circles they have been imprisoned, they are capable of expressing their desires and identities better.

What Ruhl illustrates through a comic portrayal of the nineteenth century men and women relationships is a disguised political structure that restricts women from expressing their desires and wishes. The service that Dr. Givings sells is a temporary illusion of relief, sympathy, and intimacy. These needs are considered to be signs of illness and the women in question require medical treatment. The understanding and cure for hysteria is actually a violation of women's physical bodies which are performative objects for authorities. Hysteric women were considered to be asking for attention. Their call for help was considered to be overreactions or irrational tantrums. Ruhl and Mann reflect the subjugation of women to patriarchal power through the repressive policies of the nineteenth century. After all, "Foucaultian politics," as Gary Gutting points out, "is the effort to allow the 'errors' that marginalize a group to interact creatively with the 'truths' of the mainstream society" (Gutting, 2010, p. 87).

\section{Conclusion}

Foucault states that his major interest lays in the collective response formed through individual reactions rather than just the concept of the power: "My objective, instead, has been to create a history of the different modes by which, in our culture, human beings are made subjects" (Foucault, 1982, p. 780). Dramatic texts have this advantage to put people 
Gül, S. (2021). Hysteria, madness and disciplinary power: The next room and Mrs. Packard. Humanitas, 9(18), 130-150.

under the spotlight in the middle of cultural and social networks more than other literary forms and both Mann and Ruhl use this advantage by tracing the repressive sides of power through the individual. In a way, they accomplish to create a history of the different modes on stage. Mrs. Daldry and Mrs. Packard are shown in a period in which their sanity is investigated when they step out of acceptable social norms. Both characters' struggle constitutes "an opposition to the effects of power which are linked with knowledge, competence, and qualification: struggles against the privileges of knowledge" (Foucault, 1982, p. 781). This opposition constitutes their identity and completes their individualization process.

In addition to its contribution to individualization process, Foucault's conceptualization of power also focuses on the relational aspects and productivity issues. Power is based on a complex network rather than a single source and it "runs throughout the capillaries of society" (Cooper, 1994, p. 438). Therefore, it is everywhere and resistance to power cannot be reduced to only, for example, political arena. It is difficult to draw a specific binary relationship between power and resistance as Foucault emphasizes "the socially constructed nature of interests, desires and choices" (Foucault, 1982, p. 438). Dramatic activities are capable of portraying these complex relations between people and institutions. Is power just a repressive force or can't we use it for productive purposes? Although some feminists, particularly proponents of progressive politics, argue "that the underlying assumptions of feminism are antithetical to Foucault's theoretical framework" (McLaren, 2002, p. 1), I think both plays link the notion of power to such abilities as the transformation in power systems enables everyone to adopt a progressive change. Once Mrs. Packard starts to write just like people who tried to imprison her for her ideas, her access to power creates a conscious effort to lessen the burden over women. By the same token, Mrs. Daldry's access to the vibration machine enables her to find her own feelings more clearly. What causes more problems for each character origins from the fact that power abuses scientific findings in order to maintain its superior position.

Scientific advances in medicine and genetics, albeit their contribution to different fields, have rendered human body a problematic position. Concepts of diseases, ageing, and being fit have reached to the hub of economy and culture. On the other hand, Foucault's work on sexuality, medicine and discipline launched a new approach to the general theory of government of the body (Gutting, 2005, p. 70). Similarly, both Mrs. Packard and The Next Room are reflections of the difficulties a modern life exposes and their female characters are 
Gül, S. (2021). Hysteria, madness and disciplinary power: The next room and Mrs. Packard. Humanitas, 9(18), 130-150.

stuck between their identities and the traditional role which the society expects them to perform. The reasons for this clash between two layers of social expectations are multiple, but the way Ruhl and Mann cast a historicizing light on these issues through feminist criticism also involves political intricacies embedded within a larger discursive strategy.

Mann and Ruhl also show the constructions of gender within the integration of race, class and sexuality for the white and privileged women. Although most postfeminists criticize the lack of women of color in feminist narratives, what these two white playwrights offer hints at the historical evolution of white women as vulnerable empowered subjects. It is not a coincidence that the protagonists in both plays are white and members of upper to middle class. They have been constrained to a narrow sphere of domestic activity, but their objection to the situation becomes a problem of health for them and for all the others around them. Thus, discourse analysis in both plays manifests how sociocultural hegemony of dominant groups over modes of thoughts as well as habits is established and contested. They both further Foucault's work in tracing the history of specific practices and explain how the active constitution of subject emerges in oppressive contexts.

The similarity of oppressive discourse in various forms throughout centuries is an important component that appeals to contemporary audiences who can recognize the evolution of forms of consent in these plays. Similar to the way that Foucault reveals the contingency of power and resistance in the evolution of practices and institutions, both plays focus on historical discontinuities and ruptures in terms of women rights. Mann's chronicles of small but significant details in Mrs. Packard's life explores the impact of specific events which revolve around female protagonists. The need for change in social positions is explored through Elizabeth's sufferings, but the focus expands from her miseries to the unfair dynamics of social institutions. On the other hand, Ruhl's concern with women's position and how their needs have been manipulated against them through science combines a tragicomic reading of love, orgasm, gender and relationships. Similar to Mann's approach, Ruhl exposes the difficulties women experience because of the boundaries imposed upon them by masculine values. The sociological analysis incorporated into both plays is useful for assessing how being oppressed for women has changed shapes and it still helps contemporary audiences to find responses for the topics under scrutiny. Both plays replace empirical data with fictional representations which extend and complicate some of the issues that preoccupy both scientific and feminist thought today. 


\section{References}

Cooper, D. (1994). Productive, relational and everywhere? Conceptualizing power and resistance within Foucauldian feminism. Sociology, 28(2), 435-454.

Farmer, M. (2015). I mourn the body electric: Science, technology, nature, and art in Sarah Ruhl's in the next room. Interdisciplinary Literary Studies, 7(3), 352-370.

Foucault, M. (1982). The subject of power. Critical Inquiry, 8(4), 777-795.

Foucault, M. (1990). Madness and civilization. (R. Howard, Trans.) New York: Vintage. (Original work published in 1961).

Foucault, M. (1991). The history of sexuality. Volume 1, An introduction. (R. Hurley, Trans.) New York: Vintage. (Original work published in 1976).

Foucault, M. (1995). Discipline and punishment. (A. Sheridan, Trans.) New York: Second Vintage. (Original work published in 1975).

Gilman, C. P. (1980). The Charlotte Perkins Gilman reader: The yellow wallpaper, and other fiction. New York: Pantheon Books.

Gilman, S. L. \& Showalter E., (Eds.) (1993). Hysteria beyond Freud - UC Press E-Books Collection, Berkeley: University of California Press.

Godbeer, R. (2002). Sexual revolution in early America. Baltimore MD: The Johns Hopkins Press.

Gordon, C. (2013). History of madness. In C. Falzon, O’Leary, T. \& Sawicki, J. (Eds.), A companion to Foucault: Blackwell companions to philosophy (pp. 84-104). Maiden: Blackwell Publishing.

Gutting, G. (2005). Foucault: A very short introduction. Oxford: OUP.

Kelly, K. E. (2010). Making the bones sing: The feminist history play, 1976-2010. Theatre Journal, 62(4), 645-660.

Lahr, J. (November 30, 2009) Good vibrations: Sarah Ruhl and 'Finian's rainbow' score. The New Yorker, https://www.newyorker.com/magazine/2009/11/30/good-vibrations-2.

Langworthy, D. (2014). A talk with the playwright. https://finearts.illinoisstate.edu/theatreconnections/archive/packard/\#tabs-accord-horz2.

Maines, R. P. (1999). The technology of orgasm: "Hysteria," the vibrator, and women's sexual satisfaction. Baltimore: The John Hopkins UP.

Mann, E. (2013). Mrs. Packard. New York: Broadway Play Publishing. 
Gül, S. (2021). Hysteria, madness and disciplinary power: The next room and Mrs. Packard. Humanitas, 9(18), 130-150.

Marks, P. (June 21, 2007). Injustice gone insane. Washington Post. http:://www. washingtonpost.com.

McLaren, M. A. (2002). Feminism, Foucault, and embodied subjectivity. New York: State University of New York Press.

Pickett, B. L. (2009). Historical dictionary of homosexuality. Toronto: The Scarecrow Press.

Rendell, B. (August 5, 2007). The beatification of Mrs. Packard: Emily Mann pens a stirring old fashioned social melodrama. http://talkingbroadway.com https://www.talkinbroadway.com/page/regional/nj/nj227.html.

Ruhl, S. (2010). The next room or the vibrator play. New York: Theatre Communications Group.

Schutzman, M. (1999). The real thing: Performance, hysteria, and advertising. London: UP of New England.

Thornton, E. M. (1976). Hypnotism, hysteria and epilepsy: An historical synthesis. London: William Heinemann Medical Books Limited.

VanBurkleo, S. F. (2011). Review: A world of trouble. The women's review of books, 8(6), 18-19.

Worboys, M. (2011). Practice and the science of medicine in the nineteenth century. Isis, 2(1), 109-115. 